臨床同一家系内に見られた重症筋無力症と 特発性副甲状腺機能低下症

\author{
東北大学医学部第二内科 \\ 斉藤 喬雄 ${ }^{\diamond}$ 古川洋太郎 吉永 馨 \\ 東北大学医学部第三内科 \\ 桜田 弘之

\section{MYASTHENIA GRAVIS AND IDIOPATHIC HYPOPARATHYROIDISM OCCURRING IN A FAMILY}

Takao Saito, MD, Yotaro Hurukawa, MD and Kaoru Yoshinaga, MD

The Second Department of Internal Medicine, Tohoku University

School of Medicine

Hiroyuki SAKuRADA, MD

The Third Department of Internal Medicine, Tohoku University

Schoal of Medicine

\begin{abstract}
概要 母が重症筋無力症で死亡し，子が特発性副甲状腺機能低下症と診断された症例について報告す る. 症例 1 (母)：50才，主婦．眼䀫下垂，脱力感を主訴として入院．neostigmine試験陽性．筇電 図でwaningが認められ，重症筋無力症と診断された。胸腺腫および胸腺過形成があり，胸腺切除術に

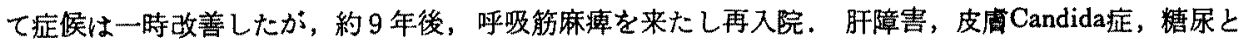
之るに，高 $\boldsymbol{\gamma}$-globulin血症，抗筇抗体の検出，phytohemagglutinin添加リンバ球培養における芽球化の 抑制等，種々の免疫異常を示唆する険查成續を呈し，死亡した。むた剖検ては，横紋筋，肝，膵，甲 状腺等にリンパ球浸潤が認められた。症例 2（子）： 30 才，男，大学病院職員。下疮の後に tetany 発作あり，血清カルシウムは低値で血清燐は高值．尿細管燐再吸収率 $99 \% ，$ Ellsworth-Howard試験で 尿中燐扰よびcyclic AMPの增加反応が著しく，特発性副甲状腺機能低下症と猃断された，その後 vitamin $\mathrm{D}_{2}$ の投与により症状は消失，検査成䋶も正常化して現在に至つている．重症筋無力症，特発 性副甲状腺機能低下症はいずれ子自己免疫機序の関与が考えられており，また，家族内での発症むし ばしば認められている。ここに報告した症例のつながりについても，遺伝的背景を持つ自己免度機序 とのかかわりを否定できないと思われる。
\end{abstract}

\section{緒言}

一種あるいは数種の自己免疫疾患が同一家系に 発症したとの報告は少なくないが，この事実は自 己免疫疾患に対する遺伝因子の関与を示唆してい るものと考劣られてる。とこで, 重症筋無力

[昭和49年 9 月 22 日 第84回東北地方会推薦]
症では胸腺腫や胸腺過形成が 高頻度に見られた り血清中に抗筋抗体や抗胸腺抗体の証明されるこ とが少なくないこと，また，しばしば慢性関節り ウマチ，全身性エリテマトーデス，橋本病等の自 己免疫疾患を合併することなどから，自己免疫疾 患の一つとして扱われることが多い(1)22．一方， 特発性副甲状腺機能低下症については，特発性 
Addison病やMonilia症との合併を来たすいわゆる HAM (hypoparathyroidism-Addison's-Monilia) 症 候群のほか子, 橋本病, 悪性貧血との合併例子見 られること(4)，Blizzardらにより抗副甲状腺抗体 が証明されたことなどから゙，自己免疫機序によ ると考えられるものがあるといわれている7゙。最 近，われわれは，多彩な症状を呈した重症筋無力 症と，特発性副甲状腺機能低下症がそれぞれ母と 息子に認められた症例を経験した。これらの疾患 が同一家系に認められた例はまだ報告されていな いようであるが，比較的希なこの二つの疾患が親 子間で見られたことは単なる偶然とは考えにく い. 自己免疫疾患之遺伝との関係に和いて, 何ら かの意味を有するるのと考え，若干の考察を加え てここに報告する。

\section{症例}

应例 1：50才, 主婦。

主訴：脱力発作，呼吸困難.

既往歴：昭和 31 年, 胆襄結石にて胆囊切除 術。

現病歴： 昭和33年頃より肩が凝りやすくなつ た. 昭和 35 年 1 月, 眼䀫下垂, 腕の脱力感が 出 現. 症状は夕方に增悪した. 同年 2 月, 東北大第 二内科に入院（第 1 回目）.

家族歴：第 3 子（症例 2) が特発性副甲状腺 機能低下症. 血族結婚なし。

入院時（第 1 回）現症：身長 $152.5 \mathrm{~cm}$, 体重 $47.9 \mathrm{~kg}$, 血圧 $114 / 64 \mathrm{~mm} H$, 栄養状態正常. 胸腹 部理学的所見に異常なし, 左眼䀫下垂あり，筋萎 縮は認められないが, 握力は左右とも $7 \mathrm{~kg}$ と低 下。

第 1 回入院後の経過： neostigmine試験陽性. 筋電図でwaningが認められ，重症筋無力症と診 断. 昭和35年 3 月より ambenonium chloride $25 \mathrm{mg} /$ 日服用により症状は改善され，4月退院した。し かし，12月頃より複視，発声障害を伴い症状增 悪し，昭和36年 2 月当科酒入院． ambenonium chlorideを60mg/日に増量したが効果なく，また同 年 5 月から 6 月にかけて胸腺 $X$ 線照射 (計 $2300 R$ )
をうけたが，握力が10〜 14kg程度に一時的に増加 したのみで，主な症状に改善はみられなからた。 昭和37年 5 月, 本学第一外科で胸腺切除術を受け た結果, ambenonium chlorideを 25mg/日に減量し ても日常生活を支障なく行なえるまでになり，同 年10月退院した。 その後, 的 9 年間著しい変化む なく過していたが，昭和 46 年秋より，また脱力感 が増強し, ambenonium chlorideを60mg/日に増量 しても効果が見られないまま，同年11月風邪気味 の後に呼吸困難となり, 本学集中治療部に入院, Birdのrespiratorにより呼吸管理を受けた。その後 自発呼吸可能となつたが，筋力の著しい低下のた め入院生活を続けていた，昭和48年 8 月, 全身の 皮虞Candida症にて高熱を発し，呼吸筋麻疰状態 に陥り，再びrespiratorを必要とした。一時, 小康 状態を得たが，同年11月19日呼吸停止および血王 低下を来たし，死亡した。なお，全経過を通し， 副腎皮質ホルモン阂，免疫抑制剤の経口および注 射による使用は行なつていない。

検查成转：第 1 回括よび第 3 回入院時の検查 成績は表 1 に示した。第 1 回入院時には前述した 如く筋電図でwaningが認められ, neostigmine test が陽性である汪か，尿クレアチンノクレアチニン 比が高值であつた，肝機能にかんしては，第 3 回 入院当初 GOT, GP T, アルカリフォスファタ 一ゼの軽度上界が認められ，尿中ウロビリノーゲ ンも強陽性であつた。 GOT， G P T はさらに上 昇し，それぞれ 198単位，225単位に達し，その 後も約半年にわたり 200単位前後の值を示したが 死亡直前に正常化した。第 3 回入院後の腎機能検 査においてクレアチニン・クリアランス，尿濃維 力等の低下があつたが，尿蛋白は常に陰性で沈渣 にも異常は認められなかつた. 第 3 回入院時, 空 腹時血糖は正常であつたが，死亡約半年前頃より

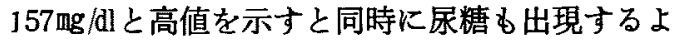
5になつた。状腺機能にかんしては，第 1 回入 院時, ${ }^{181}$ I掑取率 $6.5 \%$ と低值を示したが，P B I 等は正常でその後充分な検査はなされなかつた。

摘出胸腺所見：胸腺切除術の際，摘出された 
表 1. 症例 1，一般娭查成鈢

\begin{tabular}{|c|c|c|c|c|c|}
\hline & $\begin{array}{l}\text { 第1 回入院 } \\
\text { (昭和 } 35 \cdot 2 \text { ) }\end{array}$ & $\begin{array}{c}\text { 第 } 3 \text { 回人院 } \\
(\text { 昭和 } 46 \cdot 11)\end{array}$ & & $\begin{array}{l}\text { 第 } 1 \text { 回入院 } \\
(\text { 昭和 } 35 \cdot 2)\end{array}$ & $\begin{array}{l}\text { 第3 回入院 } \\
(\text { 昭和46.11) }\end{array}$ \\
\hline 血沈（1 時明值） & $14 \mathrm{~mm}$ & $30 \mathrm{~mm}$ & 肝機能 & & \\
\hline 末梢血所見 & & & 黃迫指数 & & 9 \\
\hline 赤血球 & $360 \times 10^{4}$ & $384 \times 10^{4}$ & $\mathrm{ZTT}$ & & 7.9 \\
\hline 血色素 (Sahli) & $75 \%$ & $82 \%$ & T T T & & 3.9 \\
\hline 白血球 & 3900 & 6300 & GOT & 24 & 56 \\
\hline 桿状球 & $3 \%$ & $2 \%$ & GPT & 24 & 41 \\
\hline 分核球 & $51 \%$ & $80 \%$ & B S P $\left(45^{\prime}\right)$ & $5 \%$ & \\
\hline 好酸球 & $1 \%$ & $0 \%$ & alk-P-ase (KA) & & 14 \\
\hline 好塩基球 & $0 \%$ & $5 \%$ & 觜機能 & & \\
\hline 単 球 & $5 \%$ & $2 \%$ & 尿秦空秦 & & $19 \mathrm{mg} / \mathrm{dl}$ \\
\hline リン八球 & $40 \%$ & $11 \%$ & 血满クレアチニン & & $0.9 \mathrm{mg} / \mathrm{dl}$ \\
\hline 尿所見 & & & 血消尿酸 & & $2.4 \mathrm{mg} / \mathrm{dl}$ \\
\hline 蛋 白 & $(-)$ & $(-)$ & クレアチニン・クリアランス & & $31.7 \mathrm{ml} / \mathrm{min}$ \\
\hline 糖 & $(-)$ & $(-)$ & 最大䈨縮力 & 1.025 & $662 \mathrm{mOsm} / \mathrm{kg} \mathrm{H} 2 \mathrm{O}$ \\
\hline ウロビリノータン & $( \pm)$ & $(\pi)$ & $\% \quad$ TRP & & 49.1 \\
\hline $\begin{array}{l}\text { 沈 渣 } \\
\text { 血清電解留 }\end{array}$ & 正常 & 正常 & $\begin{array}{l}\text { 尿酸クリアランス } \\
\text { 甲扰腺機能 }\end{array}$ & & $11.4 \mathrm{ml} / \mathrm{min}$ \\
\hline $\mathrm{Na}$ & $143 \mathrm{mEq} / l$ & $144 \mathrm{mEq} / l$ & 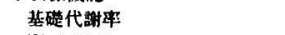 & $+3 \%$ & \\
\hline $\mathrm{K}$ & $4.3 \mathrm{mEq} / \mathrm{l}$ & $3.9 \mathrm{mEq} / \mathrm{l}$ & ${ }^{131}$ I採取平 & $6.5 \%$ & \\
\hline $\mathrm{Cl}$ & & $107 \mathrm{mEq} / \mathrm{l}$ & PBI & $7.0 \% \%$ & \\
\hline $\mathrm{Ca}_{\mathrm{a}}$ & & $9.2 \mathrm{mg} / \mathrm{dl}$ & 副腎機能 & & \\
\hline $\mathrm{P}$ & & $2.7 \mathrm{mg} / \mathrm{dl}$ & $17-\mathrm{OHCS}$ & & $2.0 \mathrm{mg} / \mathrm{d}$ \\
\hline 血溥脂斦 & & & $17-\mathrm{KS}$ & & $6.4 \mathrm{mg} / \mathrm{d}$ \\
\hline 中性脂助 & & $238 \mathrm{mg} / \mathrm{dl}$ & ACTH & & n.d. \\
\hline 脂得 & & $253 \mathrm{mg} / \mathrm{dl}$ & 荕電図 & waning & \\
\hline 堆コレステロール & $190 \mathrm{mg} / \mathrm{dl}$ & $220 \mathrm{mg} / \mathrm{dl}$ & ネオスチグミン試输 & $(+)$ & \\
\hline \multirow[t]{3}{*}{ 空腹時血糟 } & & $92 \mathrm{mg} / \mathrm{dl}$ & C P K & & \\
\hline & & & 血消コリンエステラーセ & $0.81 \Delta \mathrm{pH} / \mathrm{h}$ & $1.02 \Delta \mathrm{pH} / \mathrm{h}$ \\
\hline & & & 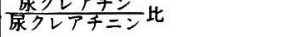 & 0.68 & 0.42 \\
\hline
\end{tabular}

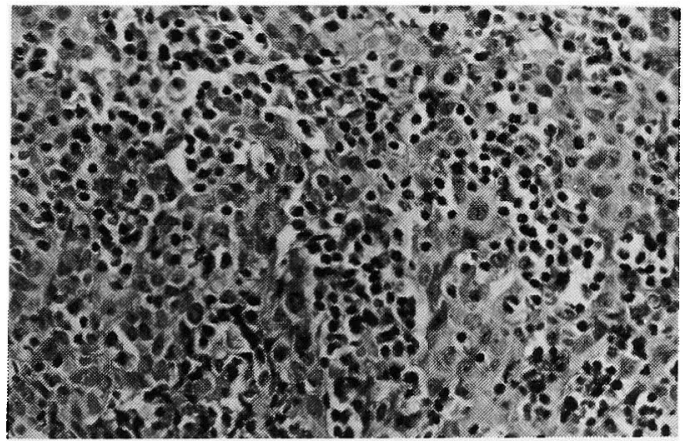

図 1. 症例 1。胸腺切除術により摘出された胸腺 腫瘍組䅧像. $\mathrm{HE}$ 染色. $\times 250$

胸腺は重量 $8.2 \mathrm{~g}$ ，大きさ $5.0 \mathrm{~cm} \times 10.5 \mathrm{~cm} \times 0.5$ cmで，一部心膜, 胸膜に癒着していた。組織学的 には，放射線照射により，ほとんどの部分が線維 成分に置き換えられていたが，一部に多角形上皮 細胞とリンパ球からなる混合型胸腺腫組織や（図 1), 肧中心やHassall小体を有する 増生組織の残 存しているのが認められた。

剖検所見：1）胸腺の遺残,胸腺腫の再発等

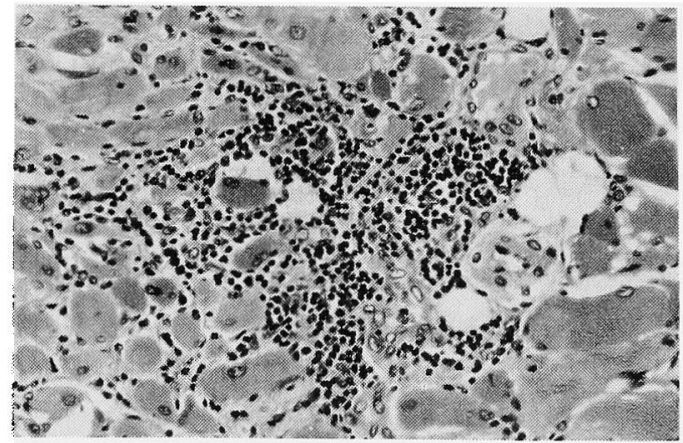

図 2. 症例 1，横紋筋剖㭘組織像. H E 染色. $\times 100$

の所見は，綻隔部をはじめ，どこにも認められな かつた．2）肉眼的に横紋筋の萎縮は著明ではな かつたが, 組織学的には巣状のリンパ球浸潤や， その周囲の筋組織の変性, 萎縮がところどころに

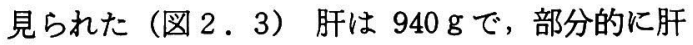
小葉改築像が認められた。また，一部ではGlisson 鞘を中心にリンパ球浸潤とそれに伴つた肝小葉周 辺部からの肝細胞の脱落が認められた（図 3 ). 肝 


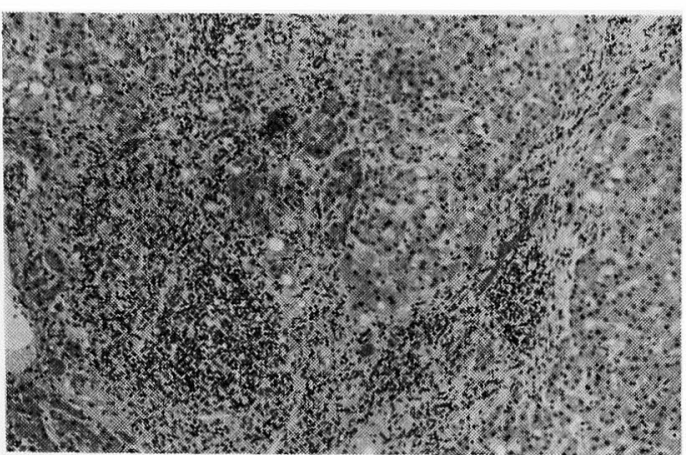

因 3. 症例 1. 肝剖検組織像. HE染色. $\times 60$

Candida症の疑われる所見はなかつた４）膵に もリンパ球浸潤および外分泌腺細胞の萎縮, 間質 の増加があつたが, Langerhans島には異常所見は 認められなかつた．5）甲状腺でも濾胞組織の萎 縮が目立ち、リンパ球の浸潤も認められたが，リ ンパ濾胞の形成等橋本病に特徵的な所見は見出せ なかつた，6）副腎では皮質部分の萎縮やリンパ
球の浸潤は認められず，下垂体もほぼ正常であつ た。 7）副甲状腺は一個摘出されたが，組織学的 に副甲状腺炎と考元られる所見は認められなかつ た８）心，肺，腎では，とくに本疾患と関係を 有すると考えられる所見はなかつた，

症例 2 : 30才, 男, 大学病院職員.

主訴：Tetany発作.

既往歴： 昭和44年, 急性腎炎にて 2 力月間入 院乙全快.

現病歴：昭和48年 2 月初め上り下脷と発熱 が 3 日間続いた。約 1 週間後手足にしびれ 感あ り, 翌日, 助産婦手位, 開口不能, 口唇孪縮等,

Tetany発作に特徵的な症状を呈し, 東北大学第三 内科に入院した. 発作時, 意識は正常で換気元進 はなかつた。

入院時現症：身長 $169.6 \mathrm{~cm}$. 体重 $62.5 \mathrm{~kg}$. 栄 責状態正常. 脈拍82整. 呼吸数20. 血圧 $122 / 74$ $\mathrm{mmHg}$. 毛髪，皮覻，爪等に異常なく，胸腹部も理

表 2. 症例 2，一般検査成績

\begin{tabular}{|c|c|c|c|}
\hline $\begin{array}{l}\text { 血沈 ( } 1 \text { 時間优) } \\
\text { 末梢血所見 }\end{array}$ & $2 \mathrm{~mm}$ & $\begin{array}{l}\text { 埾機能 } \\
\text { 䆲菜素 }\end{array}$ & $10 \mathrm{mg} / \mathrm{dl}$ \\
\hline 赤血球 & $539 \times 10^{4}$ & 血清クレアチニン & $1.1 \mathrm{mg} / \mathrm{dl}$ \\
\hline 血色素 (Sahli) & $95 \%$ & クレアチニン・クリアランス & $64.3 \mathrm{ml} / \mathrm{min}$ \\
\hline 白血球 & 4200 & $\operatorname{PSP}\left(15^{\prime}\right)$ & $47.5 \%$ \\
\hline 桿状球 & $13 \%$ & 甲状腺機能 & \\
\hline 分核球 & $31 \%$ & 基礎代碀率 & $-14 \%$ \\
\hline 好酸球 & $1 \%$ & ${ }^{131}$ I 㧴取率 & $20.9 \%$ \\
\hline 好塩韭球 & $1 \%$ & 血清サイロキシン & $8.2 \mu \mathrm{g} / \mathrm{dl}$ \\
\hline 単 球 & $6 \%$ & 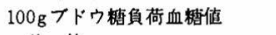 & \\
\hline リンパ球 & $48 \%$ & 前 值 & $89 \mathrm{mg} / \mathrm{dl}$ \\
\hline 尿所見 & & 30 分 & $91 \mathrm{mg} / \mathrm{dl}$ \\
\hline 蛋 白 & $(-)$ & 60 分 & $114 \mathrm{mg} / \mathrm{dl}$ \\
\hline 榶 & $(-)$ & 90 分 & $101 \mathrm{mg} / \mathrm{dl}$ \\
\hline ウロビリノーゲン & $( \pm)$ & 120 分 & $98 \mathrm{mg} / \mathrm{dl}$ \\
\hline 沈 洫 & 正常 & 150 分 & $101 \mathrm{mg} / \mathrm{dl}$ \\
\hline 血消電解征 & & 180 分 & $92 \mathrm{mg} / \mathrm{dl}$ \\
\hline $\mathrm{Na}$ & $146 \mathrm{mE} q / l$ & 副甲状腺機能 & \\
\hline $\mathrm{K}$ & $3.4 \mathrm{mEq} / l$ & 嫾クリアランス & $0.7 \mathrm{ml} / \mathrm{min}$ \\
\hline $\mathrm{Cl}$ & $102 \mathrm{mEq} / l$ & $\%$ TRP & 99.0 \\
\hline $\mathrm{Ca}$ & $5.7 \mathrm{mg} / \mathrm{dl}$ & Ellsworth-Howard 試䅋 & 反応著明 (図4) \\
\hline $\mathrm{P}$ & $5.8 \mathrm{mg} / \mathrm{dl}$ & 玏脈血酸塩基平衡 & \\
\hline 血湍脂肪 & & $\mathrm{pH}$ & 7.372 \\
\hline 中性脂肪 & $173 \mathrm{mg} / \mathrm{dl}$ & $\mathrm{PCO}_{2}$ & $38.5 \mathrm{mmHg}$ \\
\hline 燐 脂 筫 & $164 \mathrm{mg} / \mathrm{dl}$ & $\mathrm{BE}$ & $-2.5 \mathrm{mEq} / \mathrm{l}$ \\
\hline 總コレステロール & $115 \mathrm{mg} / \mathrm{dl}$ & $\mathrm{PO}_{2}$ & $76 \mathrm{mmHg}$ \\
\hline 肝機能 & & 眼科所見 & 異常なし \\
\hline 黄㡺指数 & 6 & 歯科所見 & 歯槽硬線の肥厚なし \\
\hline $\mathrm{ZTT}$ & 3.6 & 脳波所見 & 正常簕囲 \\
\hline T T T & 2.2 & 骨X線所見 & 異常なし \\
\hline GOT & 24 & & \\
\hline GPT & 10 & & \\
\hline alk-P-ase (KA) & 6.2 & & \\
\hline acid-P-ase(BL) & 0.51 & & \\
\hline
\end{tabular}




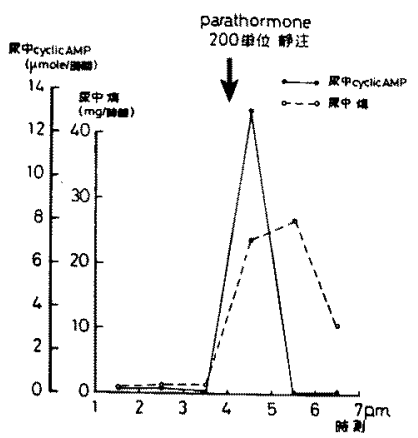

図 4，庭例 2，Ellsworth-Howard試驗

学的に異常所見なし. Chvostek徵候, Trousseau徵 候ともに陽性.

検查成鈢：入院時の主な検査成績を表 2 に示 した．血清カルシウムは低下し，血清燐は上昇し ており％ＴＲＰは高値であつた。さらに图４亿 示した如く，Ellsworth-Howard試験において，副甲 状腺ホルモン静注後燐およびcyclic AMPの尿中 への排泄が著しく增加した. 腎機能, 動脈血酸塩基 平衡は正常で，X線写真においてくる病や骨軟化 症の変化も認められなかつた. 以上の所見より,本 症例は特発性副甲状腺機能低下症々診断された。

入院後の経過：診断確定後, 乳酸カルシシウム $8 \mathrm{~g}$, Vitamin $\mathrm{D}_{2} 10$ 万単位を連日経口投与，15日 目には血清カルシウム $9.2 \mathrm{mg} / \mathrm{dl}$, 血清燐 $4.7 \mathrm{mg} / \mathrm{dl}$ と正常化，自覚症状消失した。その後第二内科 外来に打いて治療を続けているが，ひきつづき臨 床的にも検査成績にも異常は認められない。

免疫学的検索：以上の 2 症例について行なつ た免疫学的検查成續を表 3 に示した，症例 1 で は，死亡前半年以内の結果であるが，抗筋抗体は ratの横紋筋を用いた蛍光抗体間接法により 160 倍まで陽性を示した。また抗核抗体は弱陽性で抗 thyroglobulin抗体も弱いながらも陽性と考えられ る．血清蛋白分画では $\boldsymbol{\gamma}$-globulinが 高い割合を示 し，一元免疫拉散板に上る定量では補体成分 $\mathrm{C}_{3}$ が 低值であつた。さらにPHA添加りンパ球培湌に おいて芽球化率の低下が見られ，細胞免疫能の異 常を示した。一方, 症例 2 では抗thyroglobulin抗
表 3 . 免疫学的㛟查成縝

\begin{tabular}{|c|c|c|}
\hline & 拝: 殖 1 & 控例 2 \\
\hline 血消稳蛋白 & $7.0 \mathrm{~g} / \mathrm{d}$ & $6.8 \mathrm{~g} / \mathrm{dl}$ \\
\hline アルプミン & $48.0 \%$ & $67.2 \%$ \\
\hline$a_{\sharp}$ グロブリン & $4.2 \%$ & $2.9 \%$ \\
\hline$a_{2} ク$ グフンン & $9.7 \%$ & $8.3 \%$ \\
\hline Bグロブリン & $12.2 \%$ & $8.5 \%$ \\
\hline ชプロフリン & $24.9 \%$ & $13.1 \%$ \\
\hline 血讲 IgG & $1420 \mathrm{mg} / \mathrm{dl}$ & $1200 \mathrm{mg} / \mathrm{d}]$ \\
\hline $\lg A$ & $294 \mathrm{mg} / \mathrm{dl}$ & $200 \mathrm{mg} / \mathrm{dl}$ \\
\hline IgM & $63 \mathrm{mg} / \mathrm{dt}$ & $140 \mathrm{mg} / \mathrm{dl}$ \\
\hline $\mathrm{C}_{3}$ & $47 \mathrm{mg} / \mathrm{dl}$ & $70 \mathrm{mg} / \mathrm{dl}$ \\
\hline $\mathrm{C}$ & $22 \mathrm{mg} / \mathrm{dl}$ & $26 \mathrm{mg} / \mathrm{dl}$ \\
\hline 抗模抗体 & $( \pm)$ & $(-)$ \\
\hline 抗筋抗体 & $1: 160$ & $<1: 10$ \\
\hline \multicolumn{3}{|l|}{ 抗甲状腺抗体 } \\
\hline 抗マイクロサーム抗俺 & $(-)$ & $(-)$ \\
\hline 抗サイログロフリン抗体 & $1: 100$ & $1: 100$ \\
\hline RA 反店 & $(-)$ & $(-\cdots)$ \\
\hline LE反店 & $(-)$ & $(-)$ \\
\hline $\begin{array}{l}\text { PHA添加リン八球 } \\
\text { 芽球化率 }\end{array}$ & $44.5 \%$ & 328.1 (S.1.) \\
\hline
\end{tabular}

体が陽性を示したほか，異常所見は認められなか つた.

\section{考案}

重症筋無力症を自己免疫疾患として扱ら場合， その根拠として，胸腺異常を高頻度に伴うこと， 多数の例で血清中に抗筋抗体や抗胸腺抗体が検出 されること，慢性関節りウマチ，全身性エリテマ トーデス，橋本病等の自己免疫疾患を合併しやす いことなどが挙げられている゙2)。また，この疾 患はしばしば家族珄に発症するといわれている が，そのなかには他の免疫異常を伴つているるの む要る 異常を示唆する報告も多( ${ }^{910)}$ ，症例 1 は発症お よびその後の経過から, Ossermanの分類でV型に 含まれる重症筋無力症と考えられるが，この型に は胸腺腫がしばしば合併するといわれている11)。 この点, 本例に打いても胸腺腫や胸腺過形成が認 められている。さらに，細胞免疫能が低下した状 態で見られることの多い全身皮簓Candida症を合 併し ${ }^{22)}$ ，症状を悪化させた。検查上でも，血清中 の抗筋抗体の証明, $\gamma$-globulinの上昇, 補体成分 $\mathrm{C}_{8}$ の 低下，P H A 添加りンバ球芽球化率の抑制 等, 樣々な面で，免疫異常を疑わせる所見を呈し た。剖検所見で, 横紋筋のほか, 肝, 膵, 甲状腺 
などにリンパ球浸潤とそれに伴つた組織の変性， 萎縮が見られたことは，臨床所見と合わせて考虑 した場合，自己免疫機序に上り多面的に病気の進 行したことが考えられる18)14).

一方，特発性副甲状腺機能低下症には，特発性 Addison病やMonilia症を合併するいわゆるH A M 症候群や，橋本病，悪性貧血との合併が知られて 拉り，さらに，血清中の抗副甲状腺抗体の検出や 副甲状腺組織へのリンパ球浸潤の所見等から，自 己免疫機序によつて発病するるのが含まれている 可能性が指摘されている7)15)。その，本症です しばしば家族性に発症し，そのなかには他の免疫 異常を伴う場合も少なくないといわれている16) 17)，症例 2 はMonilia症やAddison病等の合併は見 られず，また免疫学的な検查成績においても明ら

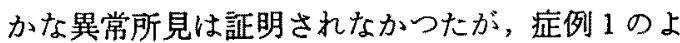
らな著明な免疫異常を伴 5 重症筋無力症患者を母 にしていることは，特発性副甲状腺機能低下症が 希な疾患であるだけに，単なる偶然とは考えがだ いそその発症は遺伝的背景を持つ自己免疫機序の 関与した，いわゆる特発性副甲状腺萎縮による可 能性があるるのと考えられる。

しかしながら，重症筋無力症と特発性副甲状腺 機能低下症は，いずれるその病因について自己免 疫のみをるつて説明するにはな和不明な部分が 少なくない、今後、これらの疾患について, 看疫 学的にさらに種々の事実が解明されたとき，ここ で報告した症例も，あらためて検討を加える要が あるであるう。

\section{結 論}

種々の免疫学的異常が認められた重症筋無力症 と，特発性副甲状腺機能低下症とがそれぞれ母 息子に発症した，これらの疾患は，ともに家族内 に発生することがあり，また，その発生に自己免 疫説が挙げられている。ここに報告した例につい ても, 遗伝学的, 免疫学的に何らかの共通の異常 を背景にしてあらわれた可能性があるものと思わ れる。

この症例を報告するにあたり，御意見をたまわりま した本学胸部外科柴生田豊講師、病理学的な面につき
御教示いただきました本学病理学䈎野伸昭教授、大藤 高志博士に感謝致します。

\section{文献}

1) 宇尾野公義 任か：重症筋無力症上自己免疫学 説。 日本臨床, $31: 284,1973 .-2)$ 玉置憲一： 重症能無力症の自己免疫。第19回日本医学会総会s 誌：1226, 1975, -3) Taitz, LS et al: Congenital absence of the parathyroid and thymus glands in an infant (III and IV Pharyngeal pouch syndrome). Pediatrics, 38: 412, 1966 . 4) Hung, $W$ et al: A possible autoimmune basis for Addison's disease in three siblings, one with idiopathic hypoparathyroidism, pernicious anemia and superficial moniliasis. New Engl $\mathrm{J}$ Med, 269: 658, 1963. -5) Kenny, FM and Holliday, MA: Hypoparathyroidism, moniliasis, Addison's and Hashimoto's disease. Hypercalcemia treated with intravenously administered sodium sulfate. New Engl J Med, 271: 708, 1964. -6) Blizzard, RM et al: The incidence of parathyroid and other antibodies in the sera of patients with idiopathic hypoparathyroidism. Clin exp Immunol, 1: 119, 1966. -7) Irvine, WJ: Adrenalitis, hypoparathyroidism and associated diseases. Samter, W. (ed.): Immunological diseases. 2nd ed Little, Brown and Company, Boston, 1971, p 1214. -8) Herrmann, $\mathrm{Jr}$ : C The familial occurrence of myasthenia gravis. Ann NY Acad. Sci, 183: 334, 1971. 一9) 川浪样子,他：筋無力症に和ける自己免疫. 日 本臨床，31:300，1973，一10) 安田美建子注： 胸腺摘出重症筋無力症患者の免疫学的検索. 臨床 免疫. $7: 551 ， 1975 .-11)$ Osserman, KE and Genkin, G: Studies in myasthenia gravis: A review of a twenty-year experience in over 1200 patients. Mount Sinai J Med, 38: 497, 1971. -12) Kirkpatrick, $\mathrm{CH}$, etal Chronic mucocutaneous candidiasis: Model-bulding in cellular immunity. Ann Intern Med, 74: 955, 1971. 一13) 土屋雅春汪加: 自己免疫性筇疾患一重症筋 無力症を中心として一診断と治療， 55：483, 1967. 一14) 有森茂：免疫異常症と胸腺. 最新医 学, $28: 1315,1973$. - 15) Van de Casseye, M and Gepts, W: Case report: Primary (autoimmune?) parathyroiditis. Virchows Arch (Pathol Anat) 361: 257, 1973. - 16) Bronsky, D et al: Familial idiopathic hypoparathyroidism. J Clin Endocrinol Metab, 28: 61, $1968 . \quad-17)$ Spinner, MW et al: B: Clinical and genetic heterogeneity in idiopathic Addison's disease and hypoparathyroidism. J Clin Endocrinol Metab, 28: 795, 1968. 